\title{
Current Developments in Lignocellulosic Biomass Conversion into Biofuels Using Nanobiotechology Approach
}

\author{
Mamata Singhvi and Beom Soo Kim * (D) \\ Department of Chemical Engineering, Chungbuk National University, Cheongju 28644, Chungbuk, Korea; \\ mamatasinghvi@gmail.com \\ * Correspondence: bskim@chungbuk.ac.kr; Tel.: +82-43-261-2372; Fax: +82-43-269-2370
}

Received: 14 September 2020; Accepted: 5 October 2020; Published: 12 October 2020

\begin{abstract}
The conversion of lignocellulosic biomass (LB) to sugar is an intricate process which is the costliest part of the biomass conversion process. Even though acid/enzyme catalysts are usually being used for LB hydrolysis, enzyme immobilization has been recognized as a potential strategy nowadays. The use of nanobiocatalysts increases hydrolytic efficiency and enzyme stability. Furthermore, biocatalyst/enzyme immobilization on magnetic nanoparticles enables easy recovery and reuse of enzymes. Hence, the exploitation of nanobiocatalysts for LB to biofuel conversion will aid in developing a lucrative and sustainable approach. With this perspective, the effects of nanobiocatalysts on LB to biofuel production were reviewed here. Several traits, such as switching the chemical processes using nanomaterials, enzyme immobilization on nanoparticles for higher reaction rates, recycling ability and toxicity effects on microbial cells, were highlighted in this review. Current developments and viability of nanobiocatalysts as a promising option for enhanced LB conversion into the biofuel process were also emphasized. Mostly, this would help in emerging eco-friendly, proficient, and cost-effective biofuel technology.
\end{abstract}

Keywords: lignocellulosic biomass; pre-treatment; biofuels; nanoparticles; nanobiocatalyst

\section{Introduction}

The emerging energy requisite raises queries about the hindrances of fossil fuels usage, in particular, their shortage in the future and adverse effects on the environment. Considering the current state, the need to search for alternative energy sources and biofuels has been augmented [1]. The swift decrease in scanty fossil fuel sources is currently a challenge for modern society [2]. Renewable and sustainable biofuel technology has been recommended as a prospective green substitute which may accomplish the global energy mandate [3]. Biofuel production using lignocellulosic biomass (LB) suggests an exceptional approach to reducing environmental pollution. The process of LB conversion into soluble sugars and corresponding bioproducts consists of numerous steps and requires precise technologies to downstream the final product [4]. The whole process of LB conversion to value-added products primarily involves: (i) pre-treatment of LB for disrupting biomass structure which makes it amenable for further enzyme attack; (ii) enzymatic hydrolysis of biomass components which releases sugars for microbial fermentation; and (iii) microbial fermentation which converts monomeric sugars into various value-added products depending on the selected strain [5] (Figure 1). 


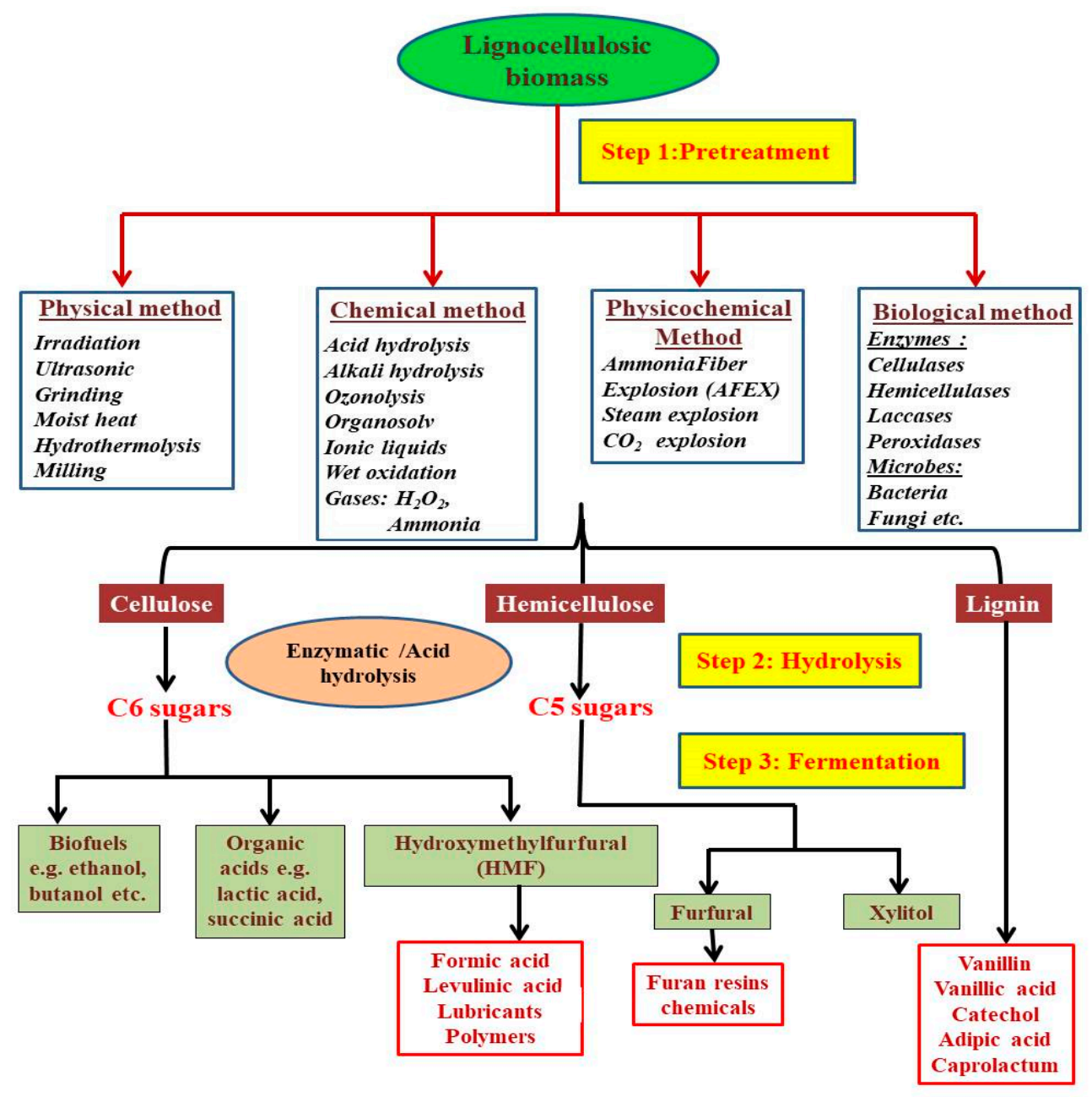

Figure 1. Three step process of lignocellulosic biomass conversion into various value-added products.

First generation biofuels are typically produced from different food crops, such as sugarcane, corn, etc., via microbial fermentation [6], but there will be food insecurity issues due to the impact on the global food supply and sustainability of the land [7]. This forced us to think about the second generation energy sources such as non-food-based LB materials for production of biofuels and chemicals. A short document prepared by the BIO-TIC project provided a concise overview of hurdles and possible solutions on biomass processing (http://www.industrialbiotech-europe.eu/wp-content/ uploads/2015/10/Summary-of-Hurdles-and-Solutions-BIO-TIC.pdf). Therefore, second generation biofuel production can be performed using feedstocks, which are inedible and abundantly available sources such as LB, agricultural waste, organic residues, etc. [8]. Second generation substrates for biofuel production generally involve the utilization of LB sources [9], which suggests an interesting solution to these problems, as they do not adversely affect the food chain.

LB is an abundantly available organic source and still remains unused in bulk amounts. The worldwide production of LB is around $1 \times 10^{10} \mathrm{MT}$ [10], which constitutes a huge resource for energy production. The global demand for LB-based products will increase day by day. LB is a complex 3-dimensional network structure mainly composed of cellulose (30-50\%), hemicellulose (25-30\%), and lignin (15-20\%) [5].

The cellulose structure is made up of a linear unbranched polymer chain of 100-1000 glucose units linked through $\beta$-glycosidic linkages. Cellulose is bundled into a structure called microfibrils which are surrounded by lignin and linked to each other by hemicellulose. The hydroxyl groups on the glucose units are linked through inter- and intra-molecular hydrogen bonds between polysaccharide chains forming microfibrils which makes the cellulose structure crystalline. In addition, the amorphous 
region of cellulose plays an important role in enzyme attack [11]. Hemicellulose is another abundantly available biopolymer which is a short and highly branched heteropolymer composed of xylose, mannose, galactose, and arabinose units. Depending on the major sugar type, they are named xyloglucans, xylans, mannans, or galactans [11].

Typically, hemicellulose represents the main xylan content in hardwoods and glucomannan in softwoods. Lignin is known as the second largely available polymer after cellulose which makes plants recalcitrant towards biological/physical attacks by providing strength [12]. Lignin is made up of monomeric phenylpropanoid units, i.e., hydroxyphenyl, guaiacyl, and syringyl units [13]. Lignin is one of the hurdles to biomass processing on the economic front, due to the presence of phenolic compounds, which impart deactivation of cellulolytic enzymes and are toxic to microbial growth. Several studies have been reported for decades regarding the conversion of lignin to monomeric and oligomeric units with further upgrading to fuels and chemicals [14].

Lignin is a well-known section of LB restricting the hydrolysis of polymeric components (i.e., cellulose and hemicellulose) using biocatalysts/enzymes. Hence, for the complete utilization of polysaccharide components, LB pre-treatment is the ultimate requirement for lignin removal [15]. After pre-treatment, the isolated cellulose/hemicellulose-rich fractions can be exploited for enzyme hydrolysis followed by fermentation. Various LB sources such as sugarcane bagasse, corn cob, corn stover, wheat straw, etc. can be utilized for biofuel fermentation. To date, numerous pre-treatment methods have been used, such as chemical, physical, biological, and physicochemical methods. However, most of the mentioned pre-treatment processes are costly and generate toxic compounds during the reaction [16]. These complications can be overcome by the emergence of a sustainable and economically viable process, such as nanobiotechnology, which provides a key to the currently available pre-treatment processes. This new nanobiotechnology method is broadly used in different fields for the production of value-added products, i.e., bioproducts and biofuels [17]. The nanobiotechnology processes comprise the use of nanoparticles (NPs). Due to the small size of NPs, they easily penetrate the cell wall of LB and intermingle with biomass constituents to release sugars [18]. NPs can be utilized in both pre-treatment and enzyme/biocatalyst hydrolysis during LB conversion process. LB pre-treatment using NPs improves the molecular and physical properties of LB components. Nowadays, magnetic NPs in fermentation broth can be easily recovered and reused for several cycles, which would make the process viable [19]. For LB hydrolysis, several enzymes, such as cellulases, hemicellulases, cellobiases, etc., have been immobilized using nanomaterials, which would serve as a cutting edge substitute to the reported methods [20]. Moreover, enzymes immobilized on NPs/nanomaterials would increase the hydrolysis rate and release larger amounts of simple sugars due to their high surface to volume ratio [21].

Despite several promising prospects, very limited studies using NPs in LB pre-treatment have been reported so far as the nanotechnology application of biorefinery is still in its nascent phase [22]. Nanomaterials can be used for LB hydrolysis using different ways, such as enzyme immobilization on nanomaterials and acid-functionalized nanomaterials. During LB hydrolysis, enzyme immobilization can prove to be an economically viable option which will make the overall process cost-effective [23]. The nanotechnology arena has recently attracted great attention as it has been applied in various fields such as biosensors, catalytic reactions, and biomedical fields [24,25]. Nanomaterials include NPs, nanocomposites (NCs), nanofibers, and nanosheets, which possess excellent properties, namely a large surface area and quantum size [26]. These fundamental characteristics of nanomaterials provide many advantages, such as higher catalytic efficiency and greater adsorption capacity [27]. There are very limited studies reported with respect to nanomaterial-associated biomass conversion into fermentable sugars [25]. In this review, we evaluate nanobiotechnology applications in the cellulosic biofuel production using microbial fermentation. The probability to decrease the overall cost of fermentative biofuel technology using nanomaterials from LB waste materials is reviewed. We also highlight the emergent role of nano- and biotechnology-based methods in LB conversion, current developments in the field, and the use of nanobiocatalysts in LB hydrolysis. In addition, pre-treatment and hydrolysis 
of LB materials using nanobiocatalysts into sugars and further biofuel fermentation using released sugars are reviewed. Furthermore, the adverse/toxic effects of nanomaterials are discussed.

\section{Lignocellulosic Biomass Pre-Treatment}

The first step in LB conversion is a pre-treatment which disrupts the complex structure of LB to release polymers. A number of pre-treatment methods, such as physical (e.g., steam explosion), chemical (e.g., acid, alkaline), physicochemical, biological, or combinations thereof [28], have been broadly studied and regularly used for isolating carbohydrates (cellulose and hemicellulose) from LB materials [29]. Still, the application of pre-treatment approaches on a commercial scale is a challenging task. Pre-treatment is an insistent obstacle for LB-based refineries, primarily due to the recalcitrant nature of LB materials, total process cost, etc. [30].

LB pre-treatment is necessary to make it more amenable towards enzyme attack. LB deconstruction is usually implemented under extremely severe operation conditions to enhance enzyme hydrolysis, making the process more expensive [31]. Chemical and biological methods have been usually employed for biomass pre-treatment. However, both methods have pros and cons. Biological methods are slower with less production capacity and chemical methods are costly due to extra steps such as neutralization, detoxification, etc. [32]. The use of costly chemicals for pre-treatment is not commercially viable. Hence, efforts have been made to explore an economical and sustainable process to convert LB to cellulose and hemicellulose for further enzymatic attack [33].

\section{Pre-Treatment of Lignocellulosic Biomass Using Nanobiotechology Approach}

It has been studied that the use of NPs or their dispersions can exhibit hydrolytic action that is nearly similar to that demonstrated using chemical pre-treatment for LB processing [34]. Treatment of wheat straw with perfluoroalkylsulfonic and alkylsulfonic acid-functionalized silica-cobalt ferrite NPs generated higher amounts of sugar $(\sim 46 \%)$ compared to the control $(\sim 35 \%)$. In addition, NPs are required in very small amounts and can be recovered from the fermentation broth and reused in the next process cycle [34]. The major benefit of employing NPs is their noteworthy role in pre-treating LB substrates using minimal amounts and their recyclability for further use. Khalid et al. [35] studied the effect of magnetic iron oxide $\left(\mathrm{Fe}_{3} \mathrm{O}_{4}\right)$ NPs on LB pre-treatment, demonstrating a significant improvement in biogas production after treatment with $\mathrm{Fe}_{3} \mathrm{O}_{4}$ magnetic NPs (MNPs). Nonetheless, so far, very little information is available on LB pre-treatment using NPs. Therefore, more efforts are required to discover probable ways of making the process economically viable on a commercial scale.

LB conversion to biofuels or other bioproducts is mainly based on pre-treatment and the enzymatic hydrolysis process. In the biomass conversion process, enzyme production is one of the costliest steps. If enzymes can be recycled using NPs, it would help improve the economics of the overall process. Recently, researchers have used nanotechnology methods to pre-treat and hydrolyze LB materials for improved biomass conversion [36]. MNPs have also been used for LB pre-treatment/enzymatic hydrolysis to easily recover enzyme/nanobiocatalyst, making the overall process cost-effective [37]. NCs containing silica functionalized with sulfonates were altered with ferrous oxide (FeO) MNPs and used as a catalyst for cellobiose hydrolysis [38]. Using alkyl sulfonate treated NPs, $78 \%$ cellobiose hydrolysis could be achieved and the NPs-associated catalyst was recovered and further reused for biomass hydrolysis. These MNPs showed significant progress in hemicellulose hydrolysis at $80^{\circ} \mathrm{C}$. The silica coated MNPs could be easily isolated from the reaction mixture using a magnet [39].

LB sources, such as corncobs pre-treated with a carbon-based solid acid catalyst, generated xylose with higher yields (78\%) using microcrystalline cellulose with $\mathrm{H}_{2} \mathrm{SO}_{4}$ [40]. A pre-treated biomass sample with protease-associated magnesium NPs (MgNPs) showed an enhanced level of amino acid generation at high temperature $\left(95^{\circ} \mathrm{C}\right)$ with increased lignin removal (18-fold) compared to cellulase pre-treated samples. MgNPs pre-treated samples that were further hydrolyzed with xylanase exhibited a 1.82-fold increase in reducing sugar production compared to untreated samples [41]. Consequently, 
nanotechnology-associated biotechnology contributes considerably to various areas such as biofuels and bioenergy.

\section{Lignocellulosic Biomass Hydrolysis}

LB hydrolysis is known to be one of the most significant steps in the biofuel fermentation process which is usually employed for degrading biomass-derived carbohydrates (cellulose and hemicellulose) into simple sugars (glucose and xylose). After hydrolysis, sugars obtained can be converted into various value-added products such as biohydrogen, bioethanol, butanol, succinic acid, lactic acid, etc. [42]. (Figure 1). LB hydrolysis determines the overall proficiency of the process which has been attained by enzymatic/biocatalytic hydrolysis and chemical hydrolysis methods. Chemical degradation processes use numerous acid catalysts such as $\mathrm{HCl}, \mathrm{H}_{2} \mathrm{SO}_{4}$, etc. for hydrolysis of different types of LB materials, resulting in lower efficiency toward sugar formation [43]. The sugar decomposition into unwanted compounds during acid hydrolysis includes furfural and hydroxymethylfurfural (HMF), which is one of the reasons for the lower efficacy of the acid hydrolysis method [44]. Limitations associated with acid hydrolysis, such as extreme operation conditions, low specificity, and generation of inhibitor toxic compounds, necessitated the development of a novel, green, and sustainable approach to LB disruption [45]. Enzymes possess better catalytic activity, selectivity, and specificity than other catalysis processes. Hence, enzymes were found to be promising biocatalysts for effective LB degradation into simple sugars [46]. The use of biocatalyst provides a green approach as no chemicals are used and thus no toxic compounds are generated. The reusability of biocatalysts/enzymes is a foremost concern in utilizing enzymes in LB hydrolysis [47]. Enzyme immobilization using various materials through crosslinking, adsorption, and covalent bonding improves enzyme stability and catalytic efficiency [48].

Enzymatic hydrolysis of LB material is recognized as a more proficient strategy than chemical hydrolysis methods. In general, specific enzymes such as cellulases, hemicellulases, and laccases are used for LB hydrolysis. Cellulases are a combination of enzymes containing endocellulase, exocellulase, and $\beta$-glucosidase which act serially/synergistically to degrade cellulosic materials. Endocellulase enzymes cleave randomly at $\beta-1,4$ internal linkages, creating free chain ends. Further, exocellulases act on 2-4 units at the ends of the exposed chains to generate disaccharides such as cellobiose. Lastly, $\beta$-glucosidase hydrolyzes cellobiose units, releasing glucose molecules [49]. There are also several other enzymes required for hemicellulose degradation, such as xylanase, $\beta$-xylosidase, glucomannase, etc. This set of enzymes can be applied to the hydrolysis of both cellulose and hemicellulose components [50]. The costly enzyme production step makes the overall process expensive, even though enzyme-mediated LB hydrolysis is an ideal method for biomass hydrolysis.

Mostly, bacterial and fungal strains are studied to produce cellulases and hemicellulases. Many bacterial species belonging to Bacillus, Cellulomonas, Thermomonospora, Caldicellulosiruptor, Erwinia, Clostridium, etc. and fungal strains including Trichoderma, Penicillium, Aspergillus, etc. are able to produce cellulases. Some strains have already been used on a commercial scale. Fungal strains usually yield higher levels of cellulases compared to bacteria. Therefore, commercially available cellulases are mainly expressed in fungi [51]. Because bacterial species lack the ability to degrade lignin, LB hydrolysis is constrained to the lignin content in LB materials [51]. Fungal strains, i.e., soft-rot, white-rot, and brown-rot fungi, are mostly used for LB hydrolysis and their action depends on the type of LB materials. These fungal species can disrupt lignin because they can secrete several lignin-degrading enzymes, i.e., laccases, lignin peroxidases ( $\mathrm{LiP})$, manganese peroxidases $(\mathrm{MnP})$, etc. Several studies have been performed on LB hydrolysis using standard commercially available cellulases [52].

Enzymatic hydrolysis is preferred over acid hydrolysis because the process is performed at ambient conditions, has a higher specificity, and does not generate inhibitor compounds. However, the cost of enzyme production primarily contributes to the increase in the overall process cost. To make the LB hydrolysis process economical, a new approach of fabricating biocatalyst on NPs/nanomaterials has recently been introduced. 
Lignocellulosic Biomass Hydrolysis Using Nanobiotechnology Approach

Recently, there has been an ingenious improvement in nanotechnology, which can be used for enzyme/biocatalyst immobilization. Immobilizing enzymes on nanomaterials is a new way to increase the catalytic efficiency of enzymes [53]. Enzymes immobilized on NPs are referred to as 'nanobiocatalyst', which is an illustration of growing and pioneering developments of nanobiotechnology [54]. Enzyme immobilization on nanomaterials through crosslinking makes it selective for substrates and more flexible due to the spacer [55].

There are numerous physical and chemical methods recommended for the immobilization of enzymes on NPs/nanomaterials. Even though a variety of methods have been studied for enzyme immobilization, comprehensive information on the association of enzyme active sites through immobilization using nanomaterials is not yet known. It has been exhibited that the active site of the enzyme plays a significant role in obtaining the resultant activity of the immobilized biocatalyst. However, it relies on the kind of process used for immobilization, the type of enzyme/biocatalyst used, and the nature of solid support [56]. It has been evident that the increased surface area of nanomaterials permits the loading of higher amounts of enzyme and decrease substrate mass transfer resistance, which is a substantial prerequisite for nanobiocatalyst development [57]. In addition, the synthesis of magnetic nanobiocatalysts by immobilizing enzymes on MNPs is preferred because these nanobiocatalysts can be easily recovered and reused in large-scale continuous processes (Figure 2). It significantly increases the life of the biocatalyst, reducing the cost of the biocatalytic process $[55,58]$.

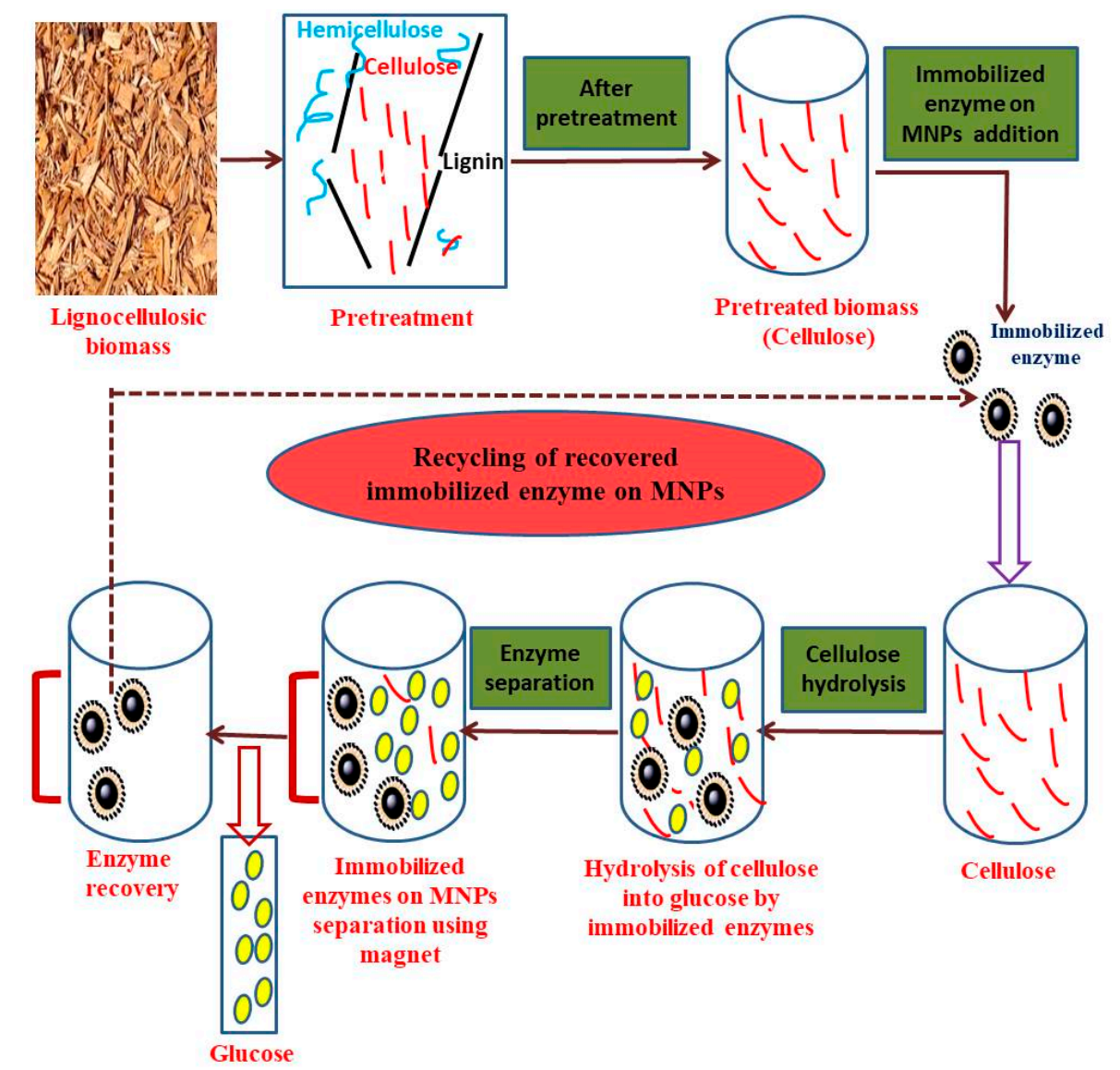

Figure 2. Schematic representation of LB-derived cellulose hydrolysis using immobilized enzymes on magnetic nanoparticles and their recovery after hydrolysis into simple sugars.

A number of nanomaterials, including MNPs, nickel nanoparticles (NiNPs), iron nanoparticles (FeNPs), and other metal oxide NPs, have been used as carriers for enzyme immobilization. Nanomaterials can potentially increase the efficiency of immobilized enzymes because they provide 
a large surface area for enzyme attachment, which helps in higher enzyme loading per unit mass of particles [59]. Enzymes immobilized on MNPs permit the reuse of enzymes for several cycles of hydrolysis due to their magnetic nature. Various studies have demonstrated that biocatalysts immobilized on MNPs can be reused for 10-15 cycles of LB hydrolysis, eliminating the need to add new enzymes every cycle. Thus, the overall process cost is reduced due to the recycling of enzymes, which can help in making the LB hydrolysis process commercially viable.

For LB hydrolysis using enzymes/biocatalysts, an enhancement in the hydrolysis rate is a key aspect of the bioconversion process [60]. Cellulases immobilized on MNPs exhibited $\sim 94 \%$ adsorption on nanomaterial support. The immobilized enzymes recovered after biomass hydrolysis still retained around 50\% enzyme activity after being reused for several cycles. The pre-treated hemp hurd biomass with immobilized enzyme and free enzyme showed $93 \%$ and $89 \%$ hydrolysis, respectively, $48 \mathrm{~h}$ after enzyme pre-treatment. Sulfonated MNPs were used for the hydrolysis of numerous LB materials such as sugarcane bagasse, jatropha, rice straws, etc. and exhibited higher LB conversion efficiency [61]. For rice straw hydrolysis, $A$. niger cellulases immobilized on cyclodextrin-based MNPs produced higher concentrations of simple sugars compared to free enzymes, with recovery of $85 \%$ immobilized enzymes for the further hydrolysis process [62]. Acid functionalized silica coated Fe-MNPs were used for LB hydrolysis and biofuel production and exhibited improved catalytic activity and stability [60].

NP-mediated enzyme catalysis (by immobilizing cellulases/hemicellulases on MNPs) could effectively produce simple sugars and biofuels from LB conversion, and immobilized enzymes could be magnetically recovered and reused [63]. Recently, enzymes immobilized on MNPs are under potential consideration as they provide numerous benefits such as biocompatibility, higher stability, larger surface area, and improved mass transfer [64]. Compared to free enzymes, enzymes immobilized on carriers such as MNPs exhibited higher thermal and pH stability [63]. Immobilized $\beta$-glucosidases on MNPs were used as a nanobiocatalyst for cellobiose hydrolysis, achieving a binding efficacy of $93 \%$. They were reused for about 15 cycles, possessing about $50 \%$ of hydrolytic activity until the last cycle [65].

For efficient hydrolysis of Avicel, cellulase was immobilized on $\mathrm{Fe}_{3} \mathrm{O}_{4} \mathrm{MNPs}$ using carbodiimide as a networking polymer and reused for 6 cycles [66]. Trichoderma reesei cellulase immobilized on chitosan-associated MNPs was used for carboxymethylcellulose hydrolysis, which retained around $80 \%$ hydrolytic activity even after reuse for 15 cycles of hydrolysis [64]. $\mathrm{Fe}_{3} \mathrm{O}_{4}$-chitosan mediated MNPs used for cellulase immobilization provided maximum LB hydrolysis at $\mathrm{pH} 5$ and $50{ }^{\circ} \mathrm{C}$ [67]. Cellulases immobilized on ferrite NPs through the glutaraldehyde crosslinking agent exhibited $53 \%$ higher LB hydrolysis at $60^{\circ} \mathrm{C}$, while remaining active until reused for the next 3 cycles [68]. Most studies demonstrated that LB hydrolysis using immobilized cellulase showed better catalysis than free enzymes [16]. Few studies exhibited that LB hydrolysis using free enzymes showed a higher hydrolytic efficiency in converting cellulose to glucose (78\%) than cellulases immobilized on MNPs (72\%) [69]. Immobilized enzymes could be reused in the next cycles with an efficiency of 60-70\%. Apart from MNPs, $\mathrm{Si}, \mathrm{Ni}$, and AgNPs have been used for cellulase immobilization in simultaneous saccharification and fermentation (SSAF) for bioethanol production from LB materials [70]. Cellulases aggregated on crosslinked magnet used for LB conversion demonstrated better hydrolysis while retaining $74 \%$ enzyme activity compared to free enzymes [21]. Chang et al. studied the effect of two different pore sized mesoporous SiNPs on biomass hydrolysis [70]. Cellulases immobilized on SiNPs with large pore size exhibited higher cellulose conversion with better stability and yield. Nickel cobaltite $\left(\mathrm{NiCo}_{2} \mathrm{O}_{4}\right)$ NPs were evaluated for their influence on cellulase production, and this study showed maximum cellulase production using NPs at a concentration of $1 \mathrm{mM}$ [71]. In addition, cellulase immobilized on $\mathrm{NiCo}_{2} \mathrm{O}_{4} \mathrm{NPs}$ improved thermostability at $80^{\circ} \mathrm{C}$ for $8 \mathrm{~h}$ compared to free enzymes, which can be one of the viable options for cellulase production from cheap sources such as LB materials [29]. Various enzymes immobilized using different types of NPs/nanomaterials are mentioned in Table 1. These immobilized biocatalysts have been further used for biomass hydrolysis. 
Table 1. Various nanomaterials used for immobilization of different enzymes.

\begin{tabular}{|c|c|c|}
\hline Nanomaterials Used on Support & Enzymes Used & References \\
\hline $\begin{array}{l}\text { Silica based NPs with carbon-derived } \\
\text { mesospores }\end{array}$ & Lipase & [36] \\
\hline MgNPs & Xylanase & [41] \\
\hline $\begin{array}{l}\text { Sulfonated magnetic carbonaceous acid } \\
\text { NPs }\end{array}$ & Cellulase & [61] \\
\hline$\beta$-cyclodextrin conjugated MNPs & Cellulase (Aspergillus niger) & [62] \\
\hline $\mathrm{Fe}_{2} \mathrm{O}_{3} \mathrm{MNPs}$ & $\beta$-glucosidase & [65] \\
\hline $\mathrm{Fe}_{3} \mathrm{O}_{4} \mathrm{MNPs}$ & Cellulase & {$[66]$} \\
\hline $\mathrm{ZnFe}_{2} \mathrm{O}_{4}$ & Cellulase & [68] \\
\hline $\begin{array}{l}\text { Sulfonated mesoporous silica modified } \\
\text { with } \mathrm{Fe}_{3} \mathrm{O}_{4} \mathrm{NPs}\end{array}$ & Cellobiase & {$[72]$} \\
\hline Zn MNPs & Cellulase & [73] \\
\hline Chitosan-based magnetic microspheres & $\beta$-glucosidase & [74] \\
\hline Superparamagnetic NPs & $\begin{array}{c}\text { Cellulases }(\beta \text {-glucosidase A and } \\
\text { cellobiohydrolase } \mathrm{D})\end{array}$ & [75] \\
\hline $\mathrm{ZnO}$ functionalized NPs & Cellulase (Aspergillus fumigatus AA001) & [76] \\
\hline $\mathrm{MnO}_{2} \mathrm{NPs}$ & Cellulase & [77] \\
\hline $\begin{array}{l}\text { Multiwall carbon nanotubes } \\
\text { functionalized with } \\
\text { N-ethyl-N-(3-dimethylaminopropyl) } \\
\text { carbodiimide hydrochloride }\end{array}$ & Cellulase (Aspergillus niger) & [78] \\
\hline $\begin{array}{l}\text { Magneto-responsive graphene } \\
\text { nanosupports }\end{array}$ & Cellulase & [79] \\
\hline
\end{tabular}

\section{Effect of Nanomaterials on Enzyme Properties}

Improvements in enzyme stability may facilitate biocatalysts/enzymes to operate under adverse conditions such as higher temperature and $\mathrm{pH}$, which will ultimately lead to the enhanced production of the final desired product [80]. An application of NPs/nanomaterials as a new approach involves the immobilization of enzyme on the surface and surrounding the protein molecules in NPs networking. Several magnetic NPs/nanomaterials were used to immobilize enzymes such as cellulase and hemicellulose, resulting in better stability than free enzymes [81-83]. Several efforts have been made to discover NPs-associated saccharification of LB materials for biofuel production [80,84].

Immobilized enzymes such as cellulases and hemicellulses exhibited higher catalytic activity and could be reused for several cycles. However, recovering the complete amount of immobilized enzyme is still impossible, which is a major obstacle to reuse [85]. In addition, enzyme immobilization improves $\mathrm{pH}$ and temperature stability, which can be beneficial in SSAF conditions where enzymatic saccharification and fermentation need to be performed using similar physical parameters $[86,87]$. Furthermore, enzyme immobilization provides a higher affinity towards LB substrates, leading to higher hydrolysis of biomass [88]. Due to the interaction of NPs and enzymes, a structure is formed in which the protein stability is altered due to changes in surface properties. Structure formation depends on the concentration and type of NPs used for enzyme immobilization $[89,90]$. Cellulases immobilized on glutaraldehyde-based iron oxide $\left(\mathrm{Fe}_{3} \mathrm{O}_{4}\right) \mathrm{NPs}$ showed a wide range of $\mathrm{pH}$ and temperature stability compared to free enzymes [88].

Several studies demonstrated similar profiles of improved cellulase stability using various $\mathrm{NPs} /$ nanomaterials such as iron oxide, nickel oxide, etc. [71,91]. Cellulases immobilized using $\mathrm{NiCo}_{2} \mathrm{O}_{4}$ exhibited increased temperature stability at $80{ }^{\circ} \mathrm{C}$ for $7 \mathrm{~h}$ compared to the control which retained stability for only $4 \mathrm{~h}$. Enzyme immobilized on $\mathrm{Fe}_{3} \mathrm{O}_{4} \mathrm{NCs}$ demonstrated improved thermal stability. From the above studies, it can be concluded that enzymes immobilized on NPs can improve the catalytic efficiency towards LB substrate hydrolysis to produce simple sugars. Table 2 describes several studies demonstrating the improvement of $\mathrm{pH}$ and temperature stability of immobilized cellulases using various nanomaterials. 
Table 2. Improvement of $\mathrm{pH}$ and temperature stability using immobilized cellulases on different types of nanomaterials.

\begin{tabular}{|c|c|c|c|}
\hline Nanomaterials Used & $\begin{array}{l}\text { Improved Physical } \\
\text { Properties }\end{array}$ & Immobilization Methods & References \\
\hline $\mathrm{MnO}_{2} \mathrm{NPs}$ & $\begin{array}{c}\text { Temperature stability at } \\
70^{\circ} \mathrm{C} \text { and pH stability at } 5.0\end{array}$ & $\begin{array}{l}\text { Covalent binding through surface } \\
\text { modification using glutaraldehyde }\end{array}$ & [77] \\
\hline $\begin{array}{c}\mathrm{Fe}_{3} \mathrm{O}_{4} / \\
\text { Chitosan NPs }\end{array}$ & $\begin{array}{c}\text { Temperature stability at } \\
60^{\circ} \mathrm{C} \text { and } \mathrm{pH} \text { stability at } 5.0\end{array}$ & $\begin{array}{l}\text { Covalent binding through surface } \\
\text { modification using glutaraldehyde }\end{array}$ & [67] \\
\hline $\mathrm{CoFe}_{2} \mathrm{O}_{4} \mathrm{NPs}$ & $\begin{array}{c}\text { Temperature stability at } \\
50^{\circ} \mathrm{C} \text { and } \mathrm{pH} \text { stability at } 5.0\end{array}$ & $\begin{array}{l}\text { Covalent binding through } \\
\text { 1-ethyl-3-(3-dimethylaminopropyl) } \\
\text { carbodiimide hydrochloride \& } \\
\text { N-hydroxysuccinimide chemistry }\end{array}$ & [92] \\
\hline $\mathrm{Fe}_{3} \mathrm{O}_{4} \mathrm{NPs}$ & $\begin{array}{c}\text { Temperature stability at } \\
60^{\circ} \mathrm{C} \text { and } \mathrm{pH} \text { stability at } 4.5\end{array}$ & $\begin{array}{l}\text { Covalent binding through surface } \\
\text { modification using glutaraldehyde }\end{array}$ & [88] \\
\hline $\mathrm{SiO}_{2} \mathrm{NPs}$ & $\mathrm{pH}$ stability at 4.8 & Physical adsorption through vinyl group & [93] \\
\hline $\mathrm{Fe}_{3} \mathrm{O}_{4} /$ Chitosan NPs & $\begin{array}{c}\text { Temperature stability at } \\
60^{\circ} \mathrm{C} \text { and pH stability at } 5.5\end{array}$ & $\begin{array}{l}\text { Covalent binding through surface } \\
\text { modification using glutaraldehyde }\end{array}$ & [64] \\
\hline $\begin{array}{l}\text { Attapulgite@chitosan } \\
\text { NCs }\end{array}$ & $\begin{array}{c}\text { Temperature stability at } \\
60^{\circ} \mathrm{C} \text { and } \mathrm{pH} \text { stability at } 4.0\end{array}$ & $\begin{array}{l}\text { Covalent binding through surface } \\
\text { modification using glutaraldehyde }\end{array}$ & [94] \\
\hline $\begin{array}{l}\mathrm{Fe}_{3} \mathrm{O}_{4} @ \mathrm{SiO}_{2} / \\
\text { graphene oxide NCs }\end{array}$ & $\begin{array}{l}\text { Temperature stability at } \\
50^{\circ} \mathrm{C} \text { and } \mathrm{pH} \text { stability at } 4.0\end{array}$ & $\begin{array}{l}\text { Covalent binding through surface } \\
\text { modification using } \\
\text { (3-aminopropyl)triethoxysilane chemistry }\end{array}$ & [95] \\
\hline $\mathrm{Fe}_{3} \mathrm{O}_{4} /$ polymer NCs & $\begin{array}{l}\text { Temperature stability in the } \\
\text { range of } 10-70^{\circ} \mathrm{C} \text { and } \mathrm{pH} \\
\text { stability in the range of } \\
2.0-8.0\end{array}$ & $\begin{array}{l}\text { Covalent binding through surface } \\
\text { modification using glutaraldehyde }\end{array}$ & [96] \\
\hline $\mathrm{Fe}_{3} \mathrm{O}_{4} @ \mathrm{SiO}_{2} \mathrm{NCs}$ & $\begin{array}{c}\text { Temperature stability at } \\
60^{\circ} \mathrm{C} \text { and } \mathrm{pH} \text { stability at } 4.5\end{array}$ & $\begin{array}{l}\text { Covalent binding through surface } \\
\text { functionalization using glycidyl } \\
\text { methacrylate }\end{array}$ & [97] \\
\hline
\end{tabular}

\section{Enzyme Immobilization}

In LB bioprocessing, enzymes play a key role in enzyme substrate reactions which lead to the generation of products depending on enzyme activity and other process conditions [98]. The use of enzymes, during the LB pre-treatment process, for generation of simple sugars, contributes to higher costs in the overall LB to biofuel conversion process. Hence, enzymes can be immobilized on NPs or any suitable support materials for improvising its properties, so as to make the enzyme application in LB pre-treatment processes economically feasible. Various groups of hydrolytic enzymes such as cellulases, xylanase, pectinase, etc. act synergistically in LB hydrolysis for biofuel production [98].

The process of enzyme immobilization refers to the confinement of enzyme in a definite region, retaining its activity in order to reuse the immobilized enzyme repeatedly without losing activity [99]. The application of enzymes when immobilized onto a support such as MNPs imparts higher stability, easy product purification, and enzyme/biocatalyst reusability [48]. In general, immobilization has been carried out using chemical bonding and physical retention methods. Physical retention includes attachment through membranes, and chemical bonding involves crosslinking and binding on supports. Enzyme binding on support material/NPs can be performed by adsorption entrapment, ionic binding, and covalent binding. From the industrial perspective, enzyme immobilization on support material through covalent bonding is the utmost method chiefly based on the interaction between the chemical groups present on the support material and enzymes [100].

Various types of support materials, inorganic and organic substrates, have been used for the immobilization of many enzymes of varying porosity, size, shape, etc. The natural inorganic supports such as clays, pumice, silica, zeolite, and manufactured materials (e.g., glass, metal oxides, alumina, ceramics, silica gel, magnetic materials) are usually used for immobilizing enzymes. In addition, some other organic carriers can be classified as natural polymers (e.g., 
cellulose, starch, dextran, agar, alginate, chitosan) for enzyme immobilization on various support materials. [99]. Support nanomaterials are linked with enzymes through crosslinking methods widely used in enzyme stabilization using dialdehydes, diiminoesters, diisocyanates, bisdiazonio salts, and carbodiimide-activated diamines to cause intermolecular bonds between the support and the enzyme/biocatalyst [101].

\section{Microbial Fermentation for Biofuel Production Using Nanobiocatalyst}

Although various $\mathrm{R} \& \mathrm{D}$ efforts have been directed towards biomass valorization over several decades, the commercial production of biofuels such as bioethanol and biodiesel still needs optimization from both technical and economical perspectives. None of the current available methods are up to the mark since their outcomes depend on the type of feedstock, downstream process configuration, and many other factors. An efficient microbial system with new metabolic routes can be used for sustainable biofuel production along with nanobiotechnology approach. At present, biohydrogen, bioethanol, biomethane, biodiesel, etc. are being studied as proficient biofuels [102]. There has been a continuous increase in energy consumption worldwide every year till date which is going to rise in the future. It is receiving great attention to improve enzyme activity and desired products during fermentation using NPs/nanomaterials [103]. However, the adverse effects of NPs/nanomaterials on LB to biofuel production have not yet been studied in detail. Only few studies have been conducted using NPs for the conversion of LB to sugar [104]. Usually, NPs/nanomaterials can have toxic effects on microbial cells when used in high concentrations. In this section, we assessed the application of nanomaterials for improved production of bioethanol and biohydrogen from LB substrates. By employing various nanomaterials during LB to biofuel fermentation, the reduction in overall cost of LB to biofuel may be possible.

\subsection{Bioethanol Production Using Various Nanomaterials}

A number of approaches have been used to make bioethanol production economical, which comprises numerous pre-treatment methods, enzymatic hydrolysis, microbial fermentation, enzyme immobilization, and genetically modified/recombinant yeast strains [105]. For bioethanol fermentation process, cellulases, cellobiase, and $\beta$-glucosidase enzymes have been immobilized on different NPs and further used for the pre-treated LB hydrolysis and showed improved properties compared to free enzymes. Numerous studies have been reported on enzyme immobilization using diverse nanomaterials such as metal NPs, metal, oxides, polymeric nanomaterials, magnetic materials, etc. $[48,103]$. For bioethanol production, $\beta$-glucosidase immobilized on metal NPs has been reported by several researchers [106-109]. Cellulase immobilized on magnetic NPs was used for Sesbania aculeate biomass hydrolysis to produce $5.31 \mathrm{~g} / \mathrm{L}$ of bioethanol and the nanobiocatalyst was reused for several recycles [110]. Verma et al. reported an immobilized thermostable $\beta$-glucosidase derived from Aspergillus niger on MNPs through covalent linking, which exhibited an immobilization efficiency of $93 \%$ and retained around $50 \%$ of the enzyme after several recycling [107]. In addition, the efficiency of $\beta$-glucosidase immobilized on chitosan-based magnetic microspheres was studied, releasing $60 \mathrm{~g} / \mathrm{L}$ of sugars during corn straw hydrolysis and maintaining conversion efficiency even after 8 rounds of biocatalyst recycling [106]. Trichoderma reesei cellulases immobilized on MNPs crosslinked through glutaraldehyde were used for hemp hurd hydrolysis to release simple sugars. The immobilized biocatalyst improved the saccharification rate and thermostability compared to free enzyme [73]. Cellulases derived from Aspergillus fumigatus were immobilized on manganese oxide NPs for bioethanol production, resulting in a binding efficiency of $75 \%$. These immobilized cellulases showed improved stability over a wide range of temperature and $\mathrm{pH}$ and were reused for 5 cycles. Finally, bioethanol production from sugarcane leaves using free and immobilized cellulase showed 18 and $22 \mathrm{~g} / \mathrm{L}$ of bioethanol, respectively [77].

Alternaria alternate cellulases immobilized on ferric oxide $\left(\mathrm{Fe}_{2} \mathrm{O}_{3}\right) \mathrm{NPs}$ were used to hydrolyze sugarcane bagasse biomass, which converted $78 \%$ cellulose to glucose at $40{ }^{\circ} \mathrm{C}$. This nanobiocatalyst 
was reused three more times, showing 52\% biomass conversion in the third cycle. [55]. All of the studies mentioned above demonstrated that immobilized biocatalysts improve $\mathrm{pH}$ and thermal stability compared to free enzymes and thus improve bioethanol production.

\subsection{Biohydrogen Production Using Nanomaterials}

Nowadays, the implementation of the nanobiotechnology approach is attracting consideration to increase the biological activity of biohydrogen production and bioproduct recovery [99]. However, the impacts of different nanomaterials on LB-derived biohydrogen production under dark fermentation conditions are still unknown. The main problems with biohydrogen production are slow production rate and low yields [111]. It has been observed that only $30-35 \%$ of the substrate is converted into biohydrogen and the residual $60-65 \%$ of the substrate leads to the production of other metabolites such as ethanol, acetic acid, butyric acid, butanol, etc. [112]. Therefore, it is important to improve the conversion efficiency from LB to biohydrogen through strain improvement using various approaches.

Hydrogenase is one of the important enzymes in biohydrogen production using dark fermentation by proton reduction. The presence of two cofactors, $\mathrm{Fe}$ and $\mathrm{Ni}$, in the active site of hydrogenase exhibited their effect in the biohydrogen production pathway during dark fermentation [113]. Hence, the productivity of hydrogen fermentation is influenced meritoriously by the presence or absence of these metal cofactors [112]. To maintain the normal functioning of microbial cells, the use of precise quantities of metal cofactors is crucial. Higher amounts of metal cofactors inhibited microbial metabolism and ultimately affected biohydrogen productivity [113]. The application of nanomaterials is a new approach to increasing metabolic activities during the process of biohydrogen production. $\mathrm{NPs}$ /nanomaterials revealed the prospective in improving ferredoxin-oxidoreductase activities, which improved the electron transfer rate corresponding to better catalytic efficiencies [114,115].

Malik et al. reported an improvement in the $\mathrm{H}_{2}$ production rate to $80.7 \mathrm{~mL} / \mathrm{h}$ using $\mathrm{Fe}_{2} \mathrm{O}_{3} \mathrm{NPs}_{\text {in }}$ the acidic $\mathrm{pH}$ range [116]. Kinetic studies also demonstrated that the level of biohydrogen production decreases with increasing substrate concentration. The effects of various NPs/nanomaterials for improving biohydrogen production are reported and summarized in Table 3.

The use of hematite $\left(\alpha-\mathrm{Fe}_{2} \mathrm{O}_{3}\right)$ and nickel oxide (NiO) NPs enhanced hydrogenase activity with a 4.5-fold increase in hydrogen production [83]. Han et al. reported a higher yield of $\mathrm{H}_{2}$ in sucrose medium in the presence of $\mathrm{Fe}_{2} \mathrm{O}_{3}$ NPs $(0.2 \mathrm{~g} / \mathrm{L})$, which was 33\% higher compared to the control medium [81]. Sugarcane bagasse biomass was hydrolyzed in a combination of diluted $\mathrm{H}_{2} \mathrm{SO}_{4}$ and titanium dioxide $\left(\mathrm{TiO}_{2}\right)$ NPs in UV light [121]. This new approach released $260 \%$ more sugar with a $127 \%$ increase in $\mathrm{H}_{2}$ production compared to the control. In addition, the influence of NiNPs on $\mathrm{H}_{2}$ production was studied, resulting in a $22.71 \%$ higher yield at $\mathrm{pH} 5.6$ and $30-35{ }^{\circ} \mathrm{C}$. In the presence of NiNPs (0.0567 wt \%), $2.54 \mathrm{~mol}$ of $\mathrm{H}_{2} / \mathrm{mol}$ of glucose was obtained under dark fermentation conditions [132]

The application of various NPs such as $\mathrm{Cu}, \mathrm{Pd}, \mathrm{Ag}, \mathrm{Fe}_{2} \mathrm{O}_{3}$ produced improved levels of $\mathrm{H}_{2}$ production from glucose by Clostridium butyricum under dark fermentation conditions. Of these NPs, $\mathrm{Fe}_{2} \mathrm{O}_{3}$ produced around $40 \%$ higher hydrogen compared to the control one [126]. The outcome of all the studies discussed here depends on the kind of interaction between enzymes and NPs/nanomaterials to improve the electron transfer rate, which ultimately enhances $\mathrm{H}_{2}$ yield and production levels. It has been demonstrated that the compact (nanometer) size of $\mathrm{Fe}_{2} \mathrm{O}_{3}$ NPs can increase the reaction rate tremendously and thus can improve hydrogenase activity by removing unnecessary oxygen from the fermentation broth [133]. Mohanraj et al. used green synthesized $\mathrm{Fe}_{2} \mathrm{O}_{3} \mathrm{NPs}$ for biohydrogen production and enhanced $\mathrm{H}_{2}$ production levels from 23.0 to $25.3 \mathrm{~mL} / \mathrm{h}$ with the yield of $2.33 \mathrm{~mol} \mathrm{H}_{2}$ per mol of substrate [125]. Recently, it was reported that $\mathrm{H}_{2}$ production was improved using FeO NPs with a $73 \%$ increase in $\mathrm{H}_{2}$ yield due to the enhancement of microbial activity associated with electron transfer between ferredoxin and hydrogenase [118].

Fe-based NPs are primarily used for biohydrogen production as Fe has been proven to be the major cofactor for hydrogenase. Besides Fe and Ni, several other NPs such as Ag, Cu, Au, Pd, etc. have been 
used for improved $\mathrm{H}_{2}$ production rate and yield under dark fermentation conditions [2,118,125,126,132]. Although the effects of different NPs on $\mathrm{H}_{2}$ production have been well studied, it is still necessary to develop strains at the molecular level to reduce NP concentrations.

Table 3. Biohydrogen production from different substrates using various nanoparticles/nanomaterials.

\begin{tabular}{|c|c|c|c|c|}
\hline Microbial Strains Used & Substrates Used & $\begin{array}{c}\text { NPs/ } \\
\text { Nanomaterials Used }\end{array}$ & $\begin{array}{c}\text { \% Increase in } \mathrm{H}_{2} \\
\text { Yield }\end{array}$ & References \\
\hline \multirow{2}{*}{ Bacillus anthracis } & Palm oil mill & $\mathrm{NiO}$ & 151 & \multirow{2}{*}{ [117] } \\
\hline & effluent & $\mathrm{CoO}$ & 167 & \\
\hline $\begin{array}{l}\text { Enterobacter sp. } \\
\text { and Clostridium sp. }\end{array}$ & Grass & $\mathrm{FeO}$ & 73.1 & [118] \\
\hline Anaerobic sludge & Sugarcane bagasse & $\mathrm{Fe}_{3} \mathrm{O}_{4}$ & 69 & [119] \\
\hline Mesophilic culture & Starch & FeNPs & 200 & [82] \\
\hline Enterobacter aerogenes & Cassava starch & $\mathrm{Fe}_{2} \mathrm{O}_{3}$ & 92 & [120] \\
\hline Anaerobic sludge containing & \multirow{2}{*}{ Molasses waste } & $\mathrm{NiO}$ & 24 & \multirow{2}{*}[83]{} \\
\hline $\mathrm{H}_{2}$ producing bacteria & & $\mathrm{Fe}_{2} \mathrm{O}_{3}$ & 43 & \\
\hline Anaerobic sludge & Sugarcane bagasse & $\mathrm{TiO}_{2}$ & 127 & [121] \\
\hline $\begin{array}{l}\text { Thermophillic anaerobic } \\
\text { mixed culture }\end{array}$ & Glucose & $\mathrm{Fe}_{2} \mathrm{O}_{3}$ & 53.6 & [122] \\
\hline Anaerobic mixed bacteria & Glucose & $\begin{array}{l}\mathrm{Fe}_{2} \mathrm{O}_{3}-\mathrm{Fe}_{3} \mathrm{O}_{4} / \text { carbon } \\
\text { nanocomposite }\end{array}$ & 33.7 & [123] \\
\hline Enterobacter cloacae & Glucose & FeNPs & 130 & [124] \\
\hline Mixed culture & Glucose & Pd(II) NPs & 9 & [125] \\
\hline Clostridium butyricum & Glucose & $\begin{array}{c}\mathrm{Pd}, \mathrm{Ag}, \mathrm{Cu} \text {, and } \mathrm{Fe} \\
\text { encapsulated } \\
\mathrm{SiO}_{2} \mathrm{NPs}\end{array}$ & 38 & [126] \\
\hline Clostridium butyricum & Sucrose & $\alpha-\mathrm{Fe}_{2} \mathrm{O}_{3}$ & 32.64 & [81] \\
\hline Anaerobic sludge & Glucose & Carbon nanotubes & $\sim 50$ & [98] \\
\hline Anaerobic sludge & Sucrose & Activated carbon & 62.5 & [127] \\
\hline Anaerobic sludge & Sucrose & Nano activated carbon & 70 & [128] \\
\hline Clostridium butyricum & Glucose & AgNPs & 67.5 & [129] \\
\hline Anaerobic sludge & Acetate & AuNPs & - & [130] \\
\hline Rhodobacter sphaeroides & Malate & $\mathrm{Fe}$ & 19.4 & [131] \\
\hline
\end{tabular}

\section{Future Perspectives}

In this review, we discussed the role of nanobiotechnology for LB conversion into simple sugars through pre-treatment and the hydrolysis process. The nanobiotechnology strategy used $\mathrm{NPs} /$ nanomaterials for biocatalyst immobilization which can easily penetrate through the LB cell wall. Thus, after interaction with nanobiocatalyst, the LB material can be more amenable towards enzyme attack for carbohydrate (cellulose and hemicellulose) conversion into sugars and further microbial fermentation to produce biofuels and other bioproducts. Most recent studies reported the use of MNPs that can recover and reuse enzymes/biocatalysts immobilized on magnetic nanomaterials by applying a magnetic field. While many studies have demonstrated the positive effects of nanomaterials on LB conversion, the thorough mechanism of NPs degrading LB structures has yet to be elucidated. The use of nanobiocatalyst for generation of sugars from LB conversion is still in its infancy. Thus, several aspects need to be studied in more detail, including the effect of NPs on enzyme functionalities, toxicity of nanomaterials in microbes during the SSAF processes, etc. Further studies are needed to evaluate the efficacy of NPs and other nanomaterials. From all of the studies discussed in this review, it can be concluded that nanomaterials are essential components for the pre-treatment and hydrolysis of LB materials for viable biofuel production. The application of nanobiotechnology would play a remarkable role in the pre-treatment and hydrolysis of LB materials.

Though NPs in powdered form have been used to produce biofuels, the use of nanosheets, nanotubes, etc. can show better binding capacity and enzyme activity. In addition, the application of biologically-derived NPs can reduce the risk of toxicity to microbial cells during fermentation. Biologically-derived NPs consist of bioactive compounds on surface matrix which might protect 
microbial cells from death/lysis. These possibilities can be implemented on a commercial scale to increase the yield and productivity of biofuels such as bioethanol and biohydrogen.

\section{Conclusions}

The search for developing efficient and sustainable pre-treatment processes is constantly an issue of huge concern for producing fermentable sugars. To date, no ideal pre-treatment process has been developed. The use of a nanobiotechnology approach provides a potential pre-treatment for LB conversion. LB hydrolysis is a fundamental stage in the biofuel production process. Acid hydrolysis methods usually generate several toxic inhibitor compounds which make the downstream process even more challenging. On the other hand, LB hydrolysis using enzymes/biocatalysts is highly specific towards substrate and more sustainable, but the enzyme production makes the overall process costlier. Immobilization of various enzymes on different metal oxides/NPs proliferates the stability and proficiency of enzymes. Additionally, immobilization of enzymes on MNPs creates nanobiocatalysts with high potential and widely recognized for LB hydrolysis. Such nanobiocatalysts possessing magnetic properties can be recovered simply by applying a magnetic field and can be reused for further processes which would make the whole process cost-effective. Nevertheless, the treatment, recycling, and preservation of NPs in pre-treatment processes need to be investigated in detail for future applications on a commercial scale.

Author Contributions: Conceptualization, M.S.; writing-review, M.S.; editing, B.S.K.; supervision, B.S.K. All authors have read and agreed to the published version of the manuscript.

Funding: This research was funded by the National Research Foundation of Korea (NRF-2019H1D3A1A01102777).

Acknowledgments: The authors acknowledge the financial support of the National Research Foundation of Korea (NRF-2019H1D3A1A01102777).

Conflicts of Interest: The authors declare no conflict of interest.

\section{Abbreviations}

\begin{tabular}{|c|c|}
\hline LB & Lignocellulosic biomass \\
\hline NPs & Nanoparticles \\
\hline MNPs & Magnetic nanoparticles \\
\hline NCs & Nanocomposites \\
\hline $\mathrm{Fe}_{3} \mathrm{O}_{4}$ & Iron (III) oxide \\
\hline $\mathrm{Fe}_{2} \mathrm{O}_{3}$ & Ferric oxide \\
\hline $\mathrm{FeO}$ & Ferrous oxide \\
\hline FeNPs & Iron nanoparticles \\
\hline SiNPs & Silica nanoparticles \\
\hline NiNPs & Nickel nanoparticles \\
\hline MgNPs & Magnesium nanoparticles \\
\hline $\mathrm{ZnO}$ & Zinc oxide \\
\hline $\mathrm{NiCO}_{2} \mathrm{O}_{4}$ & Nickel cobaltite \\
\hline $\mathrm{TiO}_{2}$ & Titanium dioxide \\
\hline LiP & Lignin peroxidase \\
\hline $\mathrm{MnP}$ & Manganese peroxidase \\
\hline SSAF & Simultaneous saccharification and fermentation \\
\hline
\end{tabular}

\section{References}

1. Rittmann, B.E. Opportunities for renewable bioenergy using microorganisms. Biotechnol. Bioeng. 2008, 100, 203-212. [CrossRef] [PubMed]

2. Mohanraj, S.; Anbalagan, K.; Rajaguru, P.; Pugalenthi, V. Effects of phytogenic copper nanoparticles on fermentative hydrogen production by Enterobacter cloacae and clostridium acetobutylicum. Int. J. Hydrogen Energy 2016, 41, 10639-10645. [CrossRef] 
3. Saravanakumar, K.; Ali, D.M.; Kathiresan, K.; Thajuddin, N.; Chen, J. Biogenic metallic nanoparticles as catalyst for bioelectricity production: A novel approach in microbial fuel cells. Mater. Sci. Eng. B 2016, 203, 27-34. [CrossRef]

4. Chen, Y.; Nielsen, J. Biobased organic acids production by metabolically engineered microorganisms. Curr. Opin. Biotechnol. 2016, 37, 165-172. [CrossRef] [PubMed]

5. Li, M. Value-Added Bioproducts Development from Lignocellulosic Biomass; Auburn University: Auburn, AL, USA, 2014.

6. Silitonga, A.S.; Masjuki, H.H.; Ong, H.C.; Sebayang, A.H.; Dharma, S.; Kusumo, F.; Siswantoro, J.; Milano, J.; Daud, K.; Mahlia, T.M.; et al. Evaluation of the engine performance and exhaust emissions of biodiesel-bioethanol-diesel blends using kernel-based extreme learning machine. Energy 2018, 159, 1075-1087. [CrossRef]

7. Clark, D.P.; Pazdernik, N.J. Basics of Biotechnology, 2nd ed.; Elsevier: Amsterdam, The Netherlands, 2016; pp. 1-31.

8. Li, C.; Aston, J.E.; Lacey, J.A.; Thompson, V.S.; Thompson, D.N. Impact of feedstock quality and variation on biochemical and thermochemical conversion. Renew. Sustain. Energy Rev. 2016, 65, 525-536. [CrossRef]

9. Milano, J.; Ong, H.C.; Masjuki, H.H.; Silitonga, A.S.; Chen, W.H.; Kusumo, F.; Dharma, S.; Sebayang, A.H. Optimization of biodiesel production by microwave irradiation-assisted transesterification for waste cooking oil-Calophyllum inophyllum oil via response surface methodology. Energy Convers. Manag. 2018, 158, 400-415. [CrossRef]

10. Sanchez, O.J.; Cardona, C.A. Trends in biotechnological production of fuel ethanol from different feedstocks. Bioresour. Technol. 2008, 99, 5270-5295. [CrossRef]

11. Singhvi, M.S.; Gokhale, D.V. Lignocellulosic biomass: Hurdles and challenges in its valorization. Appl. Microbiol. Biotechnol. 2019, 103, 9305-9320. [CrossRef]

12. Rubin, E.M. Genomics of cellulosic biofuels. Nature 2008, 454, 841-845. [CrossRef]

13. Abdel-Hamid, A.M.; Solbiati, J.O.; Cann, I.K. Insights into lignin degradation and its potential industrial applications. Adv. Appl. Microbiol. 2013, 82, 1-28. [PubMed]

14. Beckham, G.T.; Johnson, C.W.; Karp, E.M.; Salvachúa, D.; Vardon, D.R. Opportunities and challenges in biological lignin valorization. Curr. Opin. Biotechnol. 2016, 42, 40-53. [CrossRef] [PubMed]

15. Mosier, N.; Wyman, C.; Dale, B.; Elander, R.; Lee, Y.; Holtzapple, M.; Ladisch, M. Features of promising technologies for pre-treatment of lignocellulosic biomass. Bioresour. Technol. 2005, 96, 673-686. [CrossRef]

16. Kumar, A.K.; Sharma, S. Recent updates on different methods of pre-treatment of lignocellulosic feedstocks: A review. Bioresour. Bioprocess. 2017, 4, 7. [CrossRef] [PubMed]

17. Rai, M.; Ingle, A.P.; Pandit, R.; Paralikar, P.; Biswas, J.K.; da Silva, S.S. Emerging role of nanobiocatalysts in hydrolysis of lignocellulosic biomass leading to sustainable bioethanol production. Catal. Rev. 2019, 61, 1-26. [CrossRef]

18. Rai, M.; Ingle, A.P.; Gaikwad, S.; Dussán, K.J.; da Silva, S.S. Role of nanoparticles in enzymatic hydrolysis of lignocellulose in ethanol. In Nanotechnology for Bioenergy and Biofuel Production, 2nd ed.; Springer: Cham, Switzerland; Berlin/Heidelberg, Germany, 2017; pp. 153-171.

19. Periyasamy, K.; Santhalembi, L.; Mortha, G.; Aurousseau, M.; Boyer, A.; Subramanian, S. Bioconversion of lignocellulosic biomass to fermentable sugars by immobilized magnetic cellulolytic enzyme cocktails. Langmuir 2018, 34, 6546-6555. [CrossRef] [PubMed]

20. Zhang, W.; Qiu, J.; Feng, H.; Zang, L.; Sakai, E. Increase in stability of cellulase immobilized on functionalized magnetic nanospheres. J. Magn. Magn. Mater. 2015, 375, 117-123. [CrossRef]

21. Jia, J.; Zhang, W.; Yang, Z.; Yang, X.; Wang, N.; Yu, X. Novel magnetic cross-linked cellulase aggregates with a potential application in lignocellulosic biomass bioconversion. Molecules 2017, 22, 269. [CrossRef]

22. Verma, M.L. Nanobiotechnology advances in enzymatic biosensors for the agri-food industry. Environ. Chem. Lett. 2017, 15, 555-560. [CrossRef]

23. Antunes, F.A.F.; Chandel, A.K.; Teran-Hilares, R.; Ingle, A.P.; Rai, M.; dos Santos Milessi, T.S.; da Silva, S.S.; dos Santos, J.C. Overcoming challenges in lignocellulosic biomass pretreatment for second-generation (2G) sugar production: Emerging role of nano, biotechnological and promising approaches. 3 Biotech 2019, 9, 230. [CrossRef] 
24. Mudhoo, A.; Bhatnagar, A.; Rantalankila, M.; Srivastava, V.; Sillanpää, M. Endosulfan removal through bioremediation, photocatalytic degradation, adsorption and membrane separation processes: A review. Chem. Eng. J. 2019, 360, 912-928. [CrossRef]

25. Padil, V.V.T.; Wacławek, S.; Černík, M.; Varma, R.S. Tree gum-based renewable materials: Sustainable applications in nanotechnology, biomedical and environmental fields. Biotechnol. Adv. 2018, 36, $1984-2016$. [CrossRef] [PubMed]

26. Sharma, M.; Joshi, M.; Nigam, S.; Shree, S.; Avasthi, D.K.; Adelung, R.; Srivastava, S.K.; Mishra, Y. $\mathrm{ZnO}$ tetrapods and activated carbon based hybrid composite: Adsorbents for enhanced decontamination of hexavalent chromium from aqueous solution. Chem. Eng. J. 2019, 358, 540-551. [CrossRef]

27. Hokkanen, S.; Bhatnagar, A.; Sillanpää, M. A review on modification methods to cellulose-based adsorbents to improve adsorption capacity. Water Res. 2016, 91, 156-173. [CrossRef]

28. Bhatia, S.K.; Jagtap, S.S.; Bedekar, A.A.; Bhatia, R.K.; Patel, A.K.; Pant, D.; Banu, J.R.; Rao, C.V.; Kim, Y.G.; Yang, Y.H. Recent developments in pretreatment technologies on lignocellulosic biomass: Effect of key parameters, technological improvements, and challenges. Bioresour. Technol. 2020, 300, 122724. [CrossRef] [PubMed]

29. Srivastava, N.; Srivastava, M.; Manikanta, A.; Singh, P.; Ramteke, P.W.; Mishra, P.K. Nanomaterials for biofuel production using lignocellulosic waste. Environ. Chem. Lett. 2017, 15, 179-184. [CrossRef]

30. Jönsson, L.J.; Martín, C. Pre-treatment of lignocellulose: Formation of inhibitory by-products and strategies for minimizing their effects. Bioresour. Technol. 2016, 199, 103-112. [CrossRef]

31. Yoo, C.G.; Pu, Y.; Ragauskas, A.J. Ionic liquids: Promising green solvents for lignocellulosic biomass utilization. Curr. Opin. Green Sustain. Chem. 2017, 5, 5-11. [CrossRef]

32. Rocha, G.J.M.; Martín, C.; da Silva, V.F.N.; Gómez, E.O.; Gonçalves, A.R. Mass balance of pilot-scale pre-treatment of sugarcane bagasse by steam explosion followed by alkaline delignification. Bioresour. Technol. 2012, 111, 447-452. [CrossRef]

33. Furlan, F.F.; Filho, R.T.; Pinto, F.H.P.B.; Costa, C.B.B.; Cruz, A.J.G.; Giordano, R.L.C.; Giordano, R.C. Bioelectricity versus bioethanol from sugarcane bagasse: Is it worth being flexible? Biotechnol. Biofuels 2013, 6, 142. [CrossRef]

34. Leidy, P.; Ikenberry, M.; Hohn, K.L.; Wang, D. Acid-functionalized nanoparticles for pre-treatment of wheat straw. J. Biomater. Nanobiotechnol. 2012, 3, 342-352.

35. Khalid, M.J. Effect of Alkaline Pretreatment and Iron Oxide Nanoparticles on Biogas Production from Rice Straw; National University of Sciences and Technology (NUST): Islamabad, Pakistan, 2018.

36. Kumar, A.; Purohit, B.; Maurya, P.K.; Pandey, L.M.; Chandra, P. Engineered nanomaterial assisted signal-amplification strategies for enhancing analytical performance of electrochemical biosensors. Electroanalysis 2019, 31, 1615-1629. [CrossRef]

37. Verma, M.L.; Kumar, S.; Das, A.; Randhawa, J.S.; Chamundeeswari, M. Enzyme immobilization on chitin and chitosan-based supports for biotechnological applications. In Sustainable Agriculture Reviews, 2nd ed.; Crini, G., Lichtfouse, E., Eds.; Springer: Berlin/Heidelberg, Germany, 2019; pp. 147-173.

38. Bootsma, J.A.; Shanks, B.H. Cellobiose hydrolysis using organic-inorganic hybrid mesoporous silica catalysts. Appl. Catal. A 2007, 327, 44-51. [CrossRef]

39. Zhang, M.; Cushing, B.L.; O'Connor, C.J. Synthesis and characterization of monodisperse ultra-thin silica-coated magnetic nanoparticles. Nanotechnology 2008, 19, 085601. [CrossRef] [PubMed]

40. Qi, W.; He, C.; Wang, Q.; Liu, S.; Yu, Q.; Wang, W.; Leksawasdi, N.; Wang, C.; Yuan, Z. Carbon-based solid acid pretreatment in corncob saccharification: Specific xylose production and efficient enzymatic hydrolysis. ACS Sustain. Chem. Eng. 2018, 6, 3640-3648. [CrossRef]

41. Dutta, N.; Saha, M.K. Nanoparticle-induced enzyme pretreatment method for increased glucose production from lignocellulosic biomass under cold conditions. J. Sci. Food Agric. 2019, 99, 767-780. [CrossRef] [PubMed]

42. Bhatia, S.K.; Joo, H.S.; Yang, Y.H. Biowaste-to-bioenergy using biological methods-A mini-review. Energy Convers. Manag. 2018, 177, 640-660. [CrossRef]

43. Lenihan, P.; Orozco, A.; O’Neil, E.; Ahmad, M.N.M.; Rooney, D.W.; Walker, G.M. Dilute acid hydrolysis of lignocellulosic biomass. Chem. Eng. J. 2010, 156, 395-403. [CrossRef]

44. Mittal, A.; Black, S.K.; Vinzant, T.B.; O’Brien, M.; Tucker, M.P.; Johnson, D.K. Production of furfural from process-relevant biomass-derived pentoses in a biphasic reaction system. ACS Sustain. Chem. Eng. 2017, 5, 5694-5701. [CrossRef] 
45. Perna, M.D.S.C.; Bastos, R.G.; Ceccato-Antonini, S.R. Single and combined effects of acetic acid, furfural, and sugars on the growth of the pentose-fermenting yeast Meyerozyma guilliermondii. 3 Biotech 2018, 8, 119. [CrossRef]

46. Reynaldo, P.B.; Adriano, E.; Marcelo, M.; Silvia, N. Enzymatic hydrolysis of sugarcane biomass and heat integration as enhancers of ethanol production. J. Renew. Mater. 2018, 6, 183-194.

47. Chen, H.Z.; Liu, Z.H. Enzymatic hydrolysis of lignocellulosic biomass from low to high solids loading. Eng. Life Sci. 2017, 17, 489-499. [CrossRef]

48. Datta, S.; Christena, L.R.; Rajaram, Y.R.S. Enzyme immobilization: An overview on techniques and support materials. 3 Biotech. 2013, 3, 1-9. [CrossRef] [PubMed]

49. Chaturvedi, V.; Verma, P. An overview of key pre-treatment processes employed for bioconversion of lignocellulosic biomass into biofuels and value added products. 3 Biotech. 2013, 3, 415-431. [CrossRef] [PubMed]

50. Verardi, A.; De Bari, I.; Ricca, E.; Calabrò, V. Hydrolysis of lignocellulosic biomass: Current status of processes and technologies and future perspectives. In Bioethanol, 1st ed.; Lima, M.A.P., Natalense, A.P.P., Eds.; Intech Publisher: London, UK, 2012; p. 100.

51. De Souza, W.R. Microbial Degradation of lignocellulosic biomass. In Sustainable Degradation of Lignocellulosic Biomass: Techniques, Applications and Commercialization, 2nd ed.; Chandel, A.K., Da Silva, S.S., Eds.; InTech Publisher: London, UK, 2013; Volume 9, pp. 1-13.

52. Victoria, J.; Odaneth, A.; Lali, A. Importance of cellulase cocktails favouring hydrolysis of cellulose. Prep. Biochem. Biotechnol. 2017, 47, 547-553. [CrossRef] [PubMed]

53. Song, J.; Lei, T.; Yang, Y.; Wu, N.; Su, P.; Yang, Y. Attachment of enzymes to hydrophilic magnetic nanoparticles through DNA-directed immobilization with enhanced stability and catalytic activity. New J. Chem. 2018, 42, 8458-8468. [CrossRef]

54. Misson, M.; Zhang, H.; Jin, B. Nanobiocatalyst advancements and bioprocessing applications. J. R. Soc. Interface 2015, 12, 20140891. [CrossRef]

55. Ingle, A.P.; Rathod, J.; Pandit, R.; da Silva, S.S.; Rai, M. Comparative evaluation of free and immobilized cellulase for enzymatic hydrolysis of lignocellulosic biomass for sustainable bioethanol production. Cellulase 2017, 24, 5529-5540. [CrossRef]

56. Zdarta, J.; Meyer, A.S.; Jesionowski, T.; Pinelo, M. A general overview of support materials for enzyme immobilization: Characteristics, properties, practical utility. Catalysts 2018, 8, 92. [CrossRef]

57. Husain, Q.; Ansari, S.A.; Alam, F.; Azam, A. immobilization of Aspergillus oryzae beta galactosidase on zinc oxide nanoparticles via simple adsorption mechanism. Int. J. Biol. Macromol. 2011, 49, 37-43. [CrossRef]

58. Lee, S.Y.; Lee, J.; Chang, J.H.; Lee, J.H. Inorganic nanomaterial-based biocatalysts. BMB Rep. 2011, 44, 77-86. [CrossRef] [PubMed]

59. Grewal, J.; Ahmad, R.; Khare, S.K. Development of cellulase-nanoconjugates with enhanced ionic liquid and thermal stability for in situ lignocellulose saccharification. Bioresour. Technol. 2017, 242, 236-243. [CrossRef] [PubMed]

60. Wang, H.; Covarrubias, J.; Prock, H.; Wu, X.; Wang, D.; Bossmann, S.H. Acid functionalized magnetic nanoparticle as heterogeneous catalysts for biodiesel synthesis. J. Phys. Chem. C 2015, 119, 26020-26028. [CrossRef]

61. Su, T.C.; Fang, Z.; Zhang, F.; Luo, J.; Li, X.K. Hydrolysis of selected tropical plant wastes catalyzed by a magnetic carbonaceous acid with microwave. Sci. Rep. 2015, 5, 17538.

62. Huang, P.J.; Chang, K.L.; Hsieh, J.F.; Chen, S.T. Catalysis of rice straw hydrolysis by the combination of immobilized cellulase from Aspergillus niger on $\beta$-cyclodextrin- $\mathrm{Fe}_{3} \mathrm{O}_{4}$ nanoparticles and ionic liquid. Biomed. Res. Int. 2015, 1, 2015.

63. Kim, K.H.; Lee, O.K.; Lee, E.Y. Nano-immobilized biocatalysts for biodiesel production from renewable and sustainable resources. Catalysts 2018, 8, 68.

64. Sánchez-Ramírez, J.; Martínez-Hernández, J.L.; Segura-Ceniceros, P.; López, G.; Saade, H.; Medina-Morales, M.A.; Ramos-González, R.; Aguilar, C.N.; Ilyina, A. Cellulases immobilization on chitosan-coated magnetic nanoparticles: Application for agave atrovirens lignocellulosic biomass hydrolysis. Bioprocess Biosys. Eng. 2017, 40, 9-22. [CrossRef] 
65. Verma, M.L.; Chaudhary, R.; Tsuzuki, T.; Barrow, C.J.; Puri, M. Immobilization of $\beta$-glucosidase on a magnetic nanoparticle improves thermostability: Application in cellobiose hydrolysis. Bioresour. Technol. 2013, 135, 2-6. [CrossRef]

66. Jordan, J.; Kumar, C.S.S.; Theegala, C. Preparation and characterization of cellulase bound magnetite nanoparticles. J. Mol. Catal. B Enzymol. 2011, 68, 139-146. [CrossRef]

67. Zang, L.; Qiu, J.; Wu, X.; Zhang, W.; Sakai, E.; Wei, Y. Preparation of magnetic chitosan nanoparticles as support for cellulase immobilization. Ind. Eng. Chem. Res. 2014, 53, 3448-3454. [CrossRef]

68. Manasa, P.; Saroj, P.; Korrapati, N. Immobilization of cellulase enzyme on zinc ferrite nanoparticles in increasing enzymatic hydrolysis on ultrasound-assisted alkaline pretreated Crotalaria juncea biomass. Indian J. Sci. Technol. 2017, 10, 1-7. [CrossRef]

69. Yang, B.; Wyman, C.E. Effect of xylan and lignin removal by batch and flow through pretreatment on the enzymatic digestibility of corn stover cellulose. Biotechnol. Bioeng. 2004, 86, 88-95. [CrossRef] [PubMed]

70. Chang, R.H.Y.; Jang, J.; Wu, K.C.W. Cellulase immobilized mesoporous silica nanocatalysts for efficient cellulose-to-glucose conversion. Green Chem. 2011, 13, 2844-2850. [CrossRef]

71. Srivastava, N.; Rawat, R.; Sharma, R.; Oberoi, H.S.; Srivastava, M.; Singh, J. Effect of Nickel-Cobaltite Nanoparticles on Production and Thermostability of Cellulases from Newly Isolated Thermotolerant Aspergillus fumigatus NS (Class: Eurotiomycetes). Appl. Biochem. Biotechnol. 2014, 174, 1092-1103. [CrossRef]

72. Allen, S.G.; Schulman, D.; Lichwa, J.; Antal, M.J.; Jennings, E.; Elander, R. A comparison of aqueous and dilute-acid single-temperature pre-treatment of yellow poplar sawdust. Ind. Eng. Chem. Res. 2001, 40, 2352-2361. [CrossRef]

73. Abraham, R.E.; Verma, M.L.; Barrow, C.J.; Puri, M. Suitability of magnetic nanoparticle immobilised cellulases in enhancing enzymatic saccharification of pretreated hemp biomass. Biotechnol. Biofuels 2014, 7 , 90. [CrossRef]

74. Zheng, P.; Wang, J.; Lu, C.; Xu, Y.; Sun, Z. Immobilized $\beta$-glucosidase on magnetic chitosan microspheres for hydrolysis of straw cellulose. Process Biochem. 2013, 48, 683-687. [CrossRef]

75. Song, Q.; Mao, Y.; Wilkins, M.; Segato, F.; Prade, R. Cellulase immobilization on superparamagnetic nanoparticles for reuse in cellulosic biomass conversion. AIMS Bioeng. 2016, 3, 264-276. [CrossRef]

76. Srivastava, N.; Srivastava, M.; Mishra, P.; Ramteke, P.W. Application of ZnO nanoparticles for improving the thermal and $\mathrm{pH}$ stability of crude cellulase obtained from Aspergillus fumigatus AA001. Front. Microbiol. 2016, 7, 514. [CrossRef]

77. Cherian, E.; Dharmendirakumar, M.; Baskar, G. Immobilization of cellulase onto $\mathrm{MnO}_{2}$ nanoparticles for bioethanol production by enhanced hydrolysis of agricultural waste. Chin. J. Catal. 2015, 36, 1223-1229. [CrossRef]

78. Ahmad, R.; Khare, S.K. Immobilization of Aspergillus niger Cellulase on multiwall carbon nanotubes for cellulose hydrolysis. Bioresour. Technol. 2018, 252, 72-75. [CrossRef] [PubMed]

79. Gokhale, A.A.; Lu, J.; Lee, I. Immobilization of cellulase on magnetoresponsive graphene nano-supports. J. Mol. Catal. B Enzym. 2013, 90, 76-86. [CrossRef]

80. Yang, B.; Dai, Z.; Ding, S.Y.; Wyman, C.E. Enzymatic hydrolysis of cellulosic biomass. Biofuels 2011, 2, 421-449. [CrossRef]

81. Han, H.; Cui, M.; Wei, L.; Yang, H.; Shen, J. Enhancement effect of hematite nanoparticles on fermentative hydrogen production. Bioresour. Technol. 2011, 102, 7903-7909. [CrossRef] [PubMed]

82. Taherdanak, M.; Zilouei, H.; Karimi, K. The effects of $\mathrm{FeO}$ and $\mathrm{NiO}$ nanoparticles versus $\mathrm{Fe}^{2+}$ and $\mathrm{Ni}^{2+}$ ions on dark hydrogen fermentation. Int. J. Hydrogen Energy 2016, 41, 167-173. [CrossRef]

83. Gadhe, A.; Sonawane, S.S.; Varma, M.N. Enhancement effect of hematite and nickel nanoparticles on biohydrogen production from dairy wastewater. Int. J. Hydrogen Energy 2015, 40, 4502-4511. [CrossRef]

84. Singh, J.; Roychoudhury, A.; Srivastava, M.; Solanki, P.R.; Lee, D.W.; Lee, S.H.; Malhotra, B.D. A dual enzyme functionalized nanostructured thulium oxide based interface for biomedical application. Nanoscale 2014, 6, 1195-1208. [CrossRef]

85. Hosseini, S.A.; Farhadi, K.; Siahkamari, S.; Azizi, B. Catalytic wet peroxide oxidation of phenol over $\mathrm{ZnFe}_{2} \mathrm{O}_{4}$ nano spinel. Can. J. Chem. 2016, 95, 87-94. [CrossRef]

86. Ismail, I.; Hassan, M.A.; Soon, C.S. Effect of retention time on biohydrogen production by microbial consortia immobilised in polydimethylsiloxane. Afr. J. Biotechnol. 2011, 10, 601-609. 
87. Zhu, S.; Xu, X.; Rong, R.; Li, B.; Wang, X. Evaluation of zinc-doped magnetite nanoparticle toxicity in the liver and kidney of mice after sub-chronic intragastric administration. Toxicol. Res. 2016, 5, 97-106. [CrossRef]

88. Xu, J.; Huo, S.; Yuan, Z.; Zhang, Y.; Xu, H.; Guo, Y.; Liang, C.; Zhuang, X. Characterization of direct cellulase immobilization with superparamagnetic nanoparticles. Biocatal. Biotransform. 2011, 29, 71-76. [CrossRef]

89. Jariyaboon, R.; Sompong, O.; Kongjan, P. Bio-hydrogen and bio-methane potentials of skim latex serum in batch thermophilic two-stage anaerobic digestion. Bioresour. Technol. 2015, 198, 198-206. [CrossRef]

90. Kirli, B.; Kapdan, I.K. Selection of microorganism immobilization particle for dark fermentative biohydrogen production by repeated batch operation. Renew. Energy 2016, 87, 697-702. [CrossRef]

91. Srivastava, N.; Singh, J.; Ramteke, P.W.; Mishra, P.K.; Srivastava, M. Improved production of reducing sugars from rice straw using crude cellulase activated with $\mathrm{Fe}_{3} \mathrm{O}_{4}$ /alginate nanocomposite. Bioresour. Technol. 2015, 183, 262-266. [CrossRef] [PubMed]

92. Bohara, R.A.; Thorat, N.D.; Pawar, S.H. Immobilization of cellulase on functionalized cobalt ferrite nanoparticles. Korean J. Chem. Eng. 2016, 33, 216-222. [CrossRef]

93. Harmoko, C.; Sucipto, K.I.; Ery, R.S.; Hartono, S.B. Vinyl functionalized cubic mesoporous silica nanoparticles as supporting material to enhance cellulase enzyme stability. ARPN J. Eng. Appl. Sci. 2016, 11, 2981-2992.

94. Yang, C.; Mo, H.; Zang, L.; Chen, J.; Wang, Z.; Qiu, J. Surface functionalized natural inorganic nanorod for highly efficient cellulase immobilization. RSC Adv. 2016, 6, 76855-76860. [CrossRef]

95. Li, Y.; Wang, X.Y.; Jiang, X.P.; Ye, J.J.; Zhang, Y.W.; Zhang, X.Y. Fabrication of graphene oxide decorated with $\mathrm{Fe}_{3} \mathrm{O}_{4} @ \mathrm{SiO}_{2}$ for immobilization of cellulase. J. Nanopart. Res. 2015, 17, 8. [CrossRef]

96. Lima, J.S.; Araújo, P.H.H.; Sayer, C.; Souza, A.A.U.; Viegas, A.C.; de Oliveira, D. Cellulase immobilization on magnetic nanoparticles encapsulated in polymer nanospheres. Bioprocess Biosyst. Eng. 2017, 40, 511-518. [CrossRef]

97. Han, J.; Rong, J.; Wang, Y.; Liu, Q.; Tang, X.; Li, C.; Ni, L. Immobilization of cellulase on thermo-sensitive magnetic microspheres: Improved stability and reproducibility. Bioprocess Biosyst. Eng. 2018, 41, 1051-1060. [CrossRef]

98. Singh, N.; Mathur, A.S.; Barrow, C.J.; Puri, M. Enhanced cellulosic ethanol production via consolidated bioporcessing by Clostridium thermocellum ATCC 31924. Bioresour. Technol. 2018, 250, 860-867. [CrossRef] [PubMed]

99. Puri, M.; Barrow, C.J.; Verma, M.L. Enzyme immobilization on nanomaterials for biofuel production. Trends Biotechnol. 2013, 31, 215-216. [CrossRef] [PubMed]

100. Ahmad, R.; Sardar, M. Enzyme immobilization: An overview on nanoparticles as immobilization matrix. Biochem. Anal. Biochem. 2015, 4, 178.

101. Pundir, C.S. Immobilization of enzyme nanoparticles. In Enzyme Nanoparticles, 1st ed.; Pundir, C.S., Ed.; William Andrew Publishing: Boston, CA, USA, 2015; pp. 23-32.

102. Liu, Z.; Lv, F.; Zheng, H.; Zhang, C.; Wei, F.; Xing, X.H. Enhanced hydrogen production in a UASB reactor by retaining microbial consortium onto carbon nanotubes (CNTs). Int. J. Hydrogen Energy 2012, 37, 10619-10626. [CrossRef]

103. Yallappa, S.; Manjanna, J.; Sindhe, M.A.; Satyanarayan, N.D.; Pramod, S.N.; Nagaraja, K. Microwave assisted rapid synthesis and biological evaluation of stable copper nanoparticles using T. arjuna bark extract. Spectrochim. Acta A Mol. Biomol. Spectrosc. 2013, 110, 108-115. [CrossRef] [PubMed]

104. Padil, T.V.V.; Cernik, M. Green synthesis of copper oxide nanoparticles using gum karaya as a biotemplate and their antibacterial application. Int. J. Nanomed. 2013, 8, 889-898.

105. Bhatia, S.K.; Kim, S.H.; Yoon, J.J.; Yang, Y.H. Current status and strategies for second generation biofuel production using microbial systems. Energy Convers. Manag. 2017, 148, 1142-1156. [CrossRef]

106. Zhou, Y.; Pan, S.; Wei, X.; Wang, L.; Liu, Y. Immobilization of $\beta$-glucosidase onto magnetic nanoparticles and evaluation of the enzymatic properties. BioResources 2013, 8, 2605-2619. [CrossRef]

107. Alnadari, F.; Xue, Y.; Zhou, L.; Hamed, Y.S.; Taha, M.; Foda, M.F. Immobilization of $\beta$-glucosidase from Thermatoga maritima on chitin-functionalized magnetic nanoparticle via a novel thermostable chitin-binding domain. Sci. Rep. 2020, 10, 1663. [CrossRef]

108. Tsai, C.T.; Meyer, A.S. Enzymatic cellulose hydrolysis: Enzyme reusability and visualization of beta-glucosidase immobilized in calcium alginate. Molecules 2014, 19, 19390-19406. [CrossRef] 
109. Honda, T.; Tanaka, T.; Yoshino, T. Stoichiometrically controlled immobilization of multiple enzymes on magnetic nanoparticles by the magnetosome display system for efficient cellulose hydrolysis. Biomacromolecules 2015, 16, 3863-3868. [CrossRef] [PubMed]

110. Baskar, G.; Kumar, R.N.; Melvin, X.H.; Aiswarya, R.; Soumya, S. Sesbania aculeate biomass hydrolysis using magnetic nanobiocomposite of cellulase for bioethanol production. Renew. Energy 2016, 98, 23-28. [CrossRef]

111. Kapdan, I.K.; Kargi, F. Bio-hydrogen production from waste materials. Enzym. Microb. Technol. 2006, 38, 569-582. [CrossRef]

112. Logan, B.E. Biologically extracting energy from wastewater: Bio-hydrogen production and microbial fuel cells. Environ. Sci. Technol. 2004, 38, 160-167. [CrossRef] [PubMed]

113. Lin, C.Y.; Lay, C.H.; Sen, B.; Chu, C.Y.; Kumar, G.; Chen, C.C.; Chang, J.S. Fermentative hydrogen production from wastewaters: A review and prognosis. Int. J. Hydrogen Energy 2012, 37, 15632-15642. [CrossRef]

114. Van Ginkel, S.W.; Oh, S.E.; Logan, B.E. Biohydrogen gas production from food processing and domestic wastewaters. Int. J. Hydrogen Energy 2005, 30, 1535-1542. [CrossRef]

115. Bunker, C.E.; Smith, M.J. Nanoparticles for hydrogen generation. J. Mater. Chem. 2005, 21, 12173-12180. [CrossRef]

116. Malik, S.N.; Pugalenthi, V.; Vaidya, A.N.; Ghosh, P.C.; Mudliar, S.N. Kinetics of Nano-catalysed dark fermentative hydrogen production from distillery wastewater. Energy Procedia 2014, 54, 417-430. [CrossRef]

117. Mishra, P.; Thakur, S.; Mahapatra, D.M.; Wahid, Z.A.; Liu, H.; Singh, L. Impacts of nano-metal oxides on hydrogen production in anaerobic digestion of palm oil mill effluent-A novel approach. Int. J. Hydrogen Energy 2018, 43, 2666-2676. [CrossRef]

118. Yang, G.; Wang, J. Improving mechanisms of biohydrogen production from grass using zero-valent iron nanoparticles. Bioresour. Technol. 2018, 266, 413-420. [CrossRef]

119. Reddy, K.; Nasr, M.; Kumari, S.; Kumar, S.; Gupta, S.K.; Enitan, A.M.; Bux, F. Biohydrogen production from sugarcane bagasse hydrolysate: Effects of $\mathrm{pH}, \mathrm{S} / \mathrm{X}, \mathrm{Fe}^{2+}$, and magnetite nanoparticles. Environ. Sci. Pollut. Control Ser. 2017, 24, 8790-8804. [CrossRef] [PubMed]

120. Lin, R.; Cheng, J.; Ding, L.; Song, W.; Liu, M.; Zhou, J.; Cen, K. Enhanced dark hydrogen fermentation by addition of ferric oxide nanoparticles using Enterobacter aerogenes. Bioresour. Technol. 2016, 207, 213-219. [CrossRef] [PubMed]

121. Jafari, O.; Zilouei, H. Enhanced biohydrogen and subsequent biomethane production from sugarcane bagasse using nano-titanium dioxide pretreatment. Bioresour. Technol. 2016, 2014, 670-678. [CrossRef] [PubMed]

122. Engliman, N.S.; Abdul, P.M.; Wu, S.Y.; Jahim, J.M. Influence of iron (II) oxide nanoparticle on biohydrogen production in thermophilic mixed fermentation. Int. J. Hydrogen Energy 2017, 42, 27482-27493. [CrossRef]

123. Zhang, J.; Fan, C.; Zhang, H.; Wang, Z.; Zhang, J.; Song, M. Ferric oxide/carbon nanoparticles enhanced bio-hydrogen production from glucose. Int. J. Hydrogen Energy 2018, 43, 8729-8738. [CrossRef]

124. Nath, D.; Manhar, A.K.; Gupta, K.; Saikia, D.; Das, S.K.; Mandal, M. Phytosynthesized iron nanoparticles: Effects on fermentative hydrogen production by Enterobacter cloacae DH-89. Bull. Mater. Sci 2015, 38, 1533-1538. [CrossRef]

125. Mohanraj, S.; Anbalagan, K.; Kodhaiyolii, S.; Pugalenthi, V. Comparative evaluation of fermentative hydrogen production using Enterobacter cloacae and mixed culture: Effect of Pd (II) ion and phytogenic palladium nanoparticles. J. Biotechnol. 2014, 192, 87-95. [CrossRef]

126. Beckers, L.; Hiligsmann, S.; Lambert, S.D.; Heinrichs, B.; Thonart, P. Improving effect of metal and oxide nanoparticles encapsulated in porous silica on fermentative biohydrogen production by clostridium butyricum. Bioresour. Technol. 2013, 133, 109-117. [CrossRef]

127. Wimonsong, P.; Nitisoravut, R. Comparison of different catalyst for fermentative hydrogen production. J. Clean Energy Technol. 2015, 3, 128-131. [CrossRef]

128. Wimonsong, P.; Nitisoravut, R. Biohydrogen enhancement using highly porous activated carbon. Energy Fuels 2014, 28, 4554-4559. [CrossRef]

129. Zhao, W.; Zhang, Y.; Du, B.; Wei, D.; Wei, Q.; Zhao, Y. Enhancement effect of silver nanoparticles on fermentative biohydrogen production using mixed bacteria. Bioresour. Technol. 2013, 142, 240-245. [CrossRef] [PubMed]

130. Khan, M.M.; Lee, J.; Cho, M.H. Electrochemically active biofilm mediated bio-hydrogen production catalyzed by positively charged gold nanoparticles. Int. J. Hydrogen Energy 2013, 38, 5243-5250. [CrossRef] 
131. Bao, M.; Su, H.; Tan, T. Dark fermentative bio-hydrogen production: Effects of substrate pre-treatment and addition of metal ions or L-cysteine. Fuel 2013, 112, 38-44. [CrossRef]

132. Mullai, P.; Yogeswari, M.K.; Sridevi, K. Optimisation and enhancement of biohydrogen production using nickel nanoparticles-A novel approach. Bioresour. Technol. 2013, 141, 212-219. [CrossRef] [PubMed]

133. Chen, K.F.; Li, S.; Zhang, W.X. Renewable hydrogen generation by bimetallic zero valent iron nanoparticles. Chem. Eng. J. 2011, 170, 562-567. [CrossRef]

Publisher's Note: MDPI stays neutral with regard to jurisdictional claims in published maps and institutional affiliations.

(C) 2020 by the authors. Licensee MDPI, Basel, Switzerland. This article is an open access article distributed under the terms and conditions of the Creative Commons Attribution (CC BY) license (http://creativecommons.org/licenses/by/4.0/). 